\title{
The Politics of Recitation: Ideology, Interpellation, and Hegemony
}

\author{
DAVID I. BACKER
}

West Chester University

In this article, David I. Backer introduces the politics of recitation as a third realm for research on recitation pedagogy, in addition to process and product. Recitation is the pattern of classroom talk where a teacher asks a question, a student responds to the question, and the teacher evaluates the response. Research on classroom talk shows that this pattern is the dominant script in classrooms in the United States. Revisiting debates among critical theorists of schooling, particularly around the concept of hegemony, Backer argues that the politics of recitation is best understood in terms of interpellation, the concrete occurrence of ideological reproduction. He also maintains that recitation does not interpellate students into a particular category but instead teaches students to become interpellatable to any social category, independent of historical context. The article opens new possibilities for research into the connection between recitation and ideology and describes what liberatory pedagogy can look like.

Keywords: ideology, teaching methods, social structures, critical theory, Marxian analysis

Recitation-the mode of direct instruction where a teacher asks a question, a student responds to the question, and the teacher evaluates this response-is the dominant script in United States classrooms across age levels. While the word itself may sound archaic and specific, the pattern of classroom interaction it names is everywhere, from kindergarten circles to doctoral seminars. Understood in this broad sense, education discourse scholars have confirmed the persistence and predominance of recitation over generations. Hoetker and Ahlbrand (1969), following Bellack, Hyman, Kliebard, and Smith (1962), show how recitation is evident in classrooms from 1892 to 1964 . Sirotnik (1983) came to a similar conclusion, and Goodlad and Klein (1974) found that recitation persists "even in schools where considerable resources have been expended to disseminate very different ways of teaching” (Joyce \& Cal-

Harvard Educational Review Vol. 87 No. 3 Fall 2017

Copyright (C) by the President and Fellows of Harvard College 
houn, 2014, p. 1225). These studies led Cazden (1986) to call recitation the default educational pattern of communication: recitation is what we talk about when we talk about classroom talk. Nystrand, Wu, Gamoran, Zeiser, and Long (2003) confirmed once again that recitation is the default pattern of classroom communication in their detailed examination of two hundred English and social studies classrooms in the United States. In their study of 872 teacher-student interactions, more than 90 percent of these interactions were recitation patterns. And Parker's (2006, 2010) work on listening, discussion, and democratic socialization supports the claim about recitation's persistence, repeating the call for other pedagogies.

While many have described recitation and documented its frequency, fewer have examined the consequences of its prevalence. Parker $(2006,2010)$ is an exception, as he argues that authentic classroom discussion socializes students for democracy. The implication of Parker's work is that recitation socializes against democracy, though these claims are specific to the democratic quality of classroom discussion rather than the more general project of understanding recitation as a political discourse. From Parker we get a hint that recitation socializes against democracy-but what exactly does recitation socialize for? Joyce and Calhoun (2014) write that "we have little doubt that the dominance of the recitation ... is a major part of the process of socialization" (p. 1226). The word dominance here implies at least two things. First, as the researchers cited above have found, recitation's dominance means that recitation is persistent and frequent. Second, recitation socializes for dominance.

Examining the politics of recitation follows Apple's (2012) more general call to understand "how the current social order operates and . . . what schools now do in reproducing and challenging dominant institutions and relations" and, thus, "the politics of what happens to the people who work in and attend schools and the politics of the knowledge that schools teach" (p. vii). Following French Marxist Louis Althusser (2014), the politics of recitation I articulate here looks at how, during recitation, students learn a set of imagined relations to their real conditions of existence-how recitation reproduces ideology.

Focusing on ideological reproduction, rather than cultural production or resistance, runs somewhat against the grain. The tradition of critical pedagogy emerging out of Willis's $(1977,1981,1983)$ critiques of reproduction, or resistance theory, typically rejects the use of reproduction as a concept. My approach here, however, is to understand the politics of recitation, which, as we will see, requires revisiting the idea of reproduction and untangling some of the intellectual history surrounding it. While others have similarly revisited debates over resistance and reproduction to trace the origins of class-based perspectives on student resistance (McGrew, 2011), or to advance a revolutionary communist perspective on education (Malott \& Ford, 2015; Ford, 2016), my nascent project is somewhere in between: to understand concrete, everyday schooling practices from a socialist perspective (Backer, 2016b). Such a 
project requires carefully articulating concepts from debates about society and school to know what is at stake politically in dominant pedagogies like recitation.

The critical pedagogy tradition, when it has looked at recitation (Gutierrez \& Larson, 1994), uses the concept of hegemony to explain its politics. First proposed by Italian revolutionary Marxist Antonio Gramsci (1999), hegemony refers to a leadership-in-struggle that intellectuals and other cultural agents, like teachers, can use to maintain dominance or become dominant during a particular historical moment. Groups do not have natural or fixed hegemonic power; rather, they win hegemony through successful political strategy and action. Hegemony has been the preferred concept in discussions of the politics of education generally, and for good reason: Gramsci is one of the most important social theorists of the twentieth century because his understanding of political struggle is paradigmatically different than mechanistic interpretations thereof associated with Russian Communist philosophy and politics after 1930. Gramsci's key insight was a geological view of politics as a terrain where entrenched and contradictory forces, hegemonic and counterhegemonic persons and groups, fight to make gains for their causes in relatively autonomous ways. Gramsci's geological view, an interpretation of Vladimir Lenin's political philosophy and strategy, was an important alternative (some would say corrective) to the teleological, deterministic view offered by Josef Stalin (1939) and others.

In education theory, this difference between Gramscian geological flexibility and Stalinist mechanistic rigidity has informed intellectual interpretations of resistance and reproduction, respectively. Willis's and others' critiques of reproduction more or less follow this pattern, defining reproduction as a mechanical concept. However, as I will show, the geologic/mechanistic and resistance/reproduction dyads are not configured this way when it comes to recitation. Though it has been characterized as such, reproduction is not an inherently mechanistic concept. Reproduction occurs even if one understands politics geologically. For example, while cultural production theory examines how ideological influence is minced, blocked, or otherwise complicated through bottom-up resistance by specific students and teachers in the political terrain (Willis, 1977, p. 186), ideological reproduction theory looks at that initial ideological influence and how it works in the same political terrain. In schools, recitation is a frequent and persistent technique that plays a role in the balance of forces where groups attempt to maintain hegemony, or compete to upend that hegemony. Therefore, rather than solely a question of hegemony, the politics of recitation is also one of ideological influence as the competition for hegemony rages on in the political terrain. Recitation's role in the process of ideological influence, I will show, is one of recruitment-how dominant groups try to recruit young people to their dominant ideology. Does recitation recruit students to specific ideologies through what Althusser (2014) calls 
the "process of interpellation," or, as I claim, does it teach students to become recruitable for any category whatsoever-what I call interpellatability?

In the first half of this article, I look at the ways educational researchers have understood and continue to understand recitation as a pattern of teacher-student communication following an initiation-response-evaluation script. I then move on to consider existing arguments about the politics of recitation that characterize it as a hegemonic discourse. After revisiting the notion of hegemony, as well as the intellectual history surrounding Willis's arguments against reproduction theory in the sociology of education, I argue that the politics of recitation should be recast in terms of interpellation, Althusser's term for a discrete instance of ideological reproduction. I then articulate a thesis about the politics of recitation. This interpellatability thesis understands recitation's politics as teaching students to become interpellatable, a neologism. Just as someone who is persuadable is easily persuaded, for instance, someone who is interpellatable is easily interpellated. As I elaborate in the second half of the article, if an interpellation is a discrete instance of ideological reproduction, interpellatability is the quality that makes an individual receptive to ideological reproduction in any context. Whereas Gutierrez and Larson (1994) argue that recitation is an interpellative discourse that socializes students into a particular category, I contend that recitation is a discourse of interpellatability that teaches students to become socializable. I conclude by placing this argument in the tradition of educational research on recitation and proposing avenues for further research in critical education discourse theory. The article offers a new understanding of recitation's political significance; a reexamination of foundational concepts in the sociology of education, such as hegemony, interpellation, and reproduction; and a political response to lingering questions about the persistence of recitation in classrooms.

\section{Recitation: Process and Product}

Traditionally, a recitation occurs when a teacher calls on a student and that student recites some piece of knowledge they have memorized. In generations past, this meant religious texts; in modern contexts, secular information, such as grammar, arithmetic, and history, form the curriculum for recitations (Thayer, 1928). Education discourse analysts have updated this older definition, however. Cazden (1986) uses the acronym IRE to define recitation: teacher initiation, student response, and teacher evaluation-repeat. She sees recitation as a continuous script wherein the teacher is perpetually initiating, typically with questions, then evaluating what students say in response to these initiations by saying "right" or "good" or offering any attribution of worth or value, such as "interesting" or "okay." The following are observable behaviors in a classroom that flow from the IRE conception of recitation: 
In recitation, ideas are not explored, but rather answers are provided to teachers' questions. (Cazden, 1986, p. 54)

"In recitation there is a predominant speaker, and that is the teacher; typically, the teacher speaks about two thirds of time." (Dillon, 1994, p. 16)

"In recitation we hear a characteristic exchange of talk, most easily described as ... question-answer from teacher and student (not from student and teacher)." (Dillon, 1994, p. 16)

"Recitation has a predictable sequence of talk: first the teacher, then a student will speak. The sequence is almost always teacher-student, nothing else. You can bet your money on that and win nine times out of ten." (Dillon, 1994, p. 18)

Students do not "decide when to speak" but rather wait "to be called on by the teacher." (Cazden, 1986, p. 54)

In recitation, "teachers have the right to speak at any time and to any person; they can fill any silence or interrupt any speaker . . . and no one has any right to object." (Cazden, 1986, p. 54)

These indicators are procedural because they address the way in which a recitation is facilitated: the turns taken, the pauses used, the status of eye contact, etc. It is important to note here that Cazden's description of recitation is not content-specific. A recitation could be about any subject as long as it includes a homogeneous sequence of turns, a short wait time, and/or the teacher regaining the floor. The procedural aspect of recitation emphasizes its status as a form of interaction and pedagogy rather than any particular content. Students might have history, mathematics, literature, and science classes where the content is totally distinct, yet their teachers might all use recitation to teach those lessons. In this case, the classroom content changes while the classroom process stays the same.

In addition to a process, recitation also facilitates a certain kind of learning in the classroom. This product of recitation is still content-independent, but it has more to do with what students learn about that content because they have learned it through recitation. Note Dewey's (1998) description of recitation as the teacher's art:

In the recitation the teacher comes into his closest contact with the pupil. The recitation focuses on the possibilities of guiding children's activities, influencing their language habits, and directing their observations ... The method in which the recitation is carried on is a crucial test of a teacher's skill in diagnosing the intellectual state of his pupils and in supplying the conditions that will arouse serviceable mental responses: in short, of his art as a teacher. (p. 202)

Dewey describes recitation's close contact between teacher and student, which allows a teacher to "diagnose" intellectual states and "supply the conditions" for "serviceable mental responses." He goes so far as to claim that the recitation is the teacher's "art." 
Following Dewey, and extrapolating from education discourse analysis from the 1980 s to now, it is clear that teachers rely heavily on recitation. Though there may be drawbacks to recitation, its process and product are frequently found in classrooms; it is functional for those teachers who use it (Stodolsky, Ferguson, \& Wimpelberg, 1981) and has been deemed effective by the likes of John Dewey.

Aside from its process and product, researchers have also focused on the power dynamic between teachers and students engaged in recitation, and the significance of this dynamic for society at large. Drawing from Russian literary theorist Mikhail Bakhtin, Nystrand et al. (2003) argue that recitation is "monological." Monologue, for Bakhtin, is a species of communication that "is finalized and deaf to the other's response, does not expect it and does not acknowledge it in it any decisive force" (Nystrand et al., 2003, p. 3). Monologue is also official; those who want to have the final word in a conversation will speak monologically. Nystrand et al. (2003) characterize recitation as a token of the monologic species:

The recitation taking place in typical school settings seeks to elicit "official" answers originating in texts transmitted only one way-from teachers to students, to be received and recalled intact by students. The resulting monologic discourse . . is one in which the relationship of teacher and student is restricted to that of evaluator and novice, organized for the transmission of information [where] students have little chance of becoming conversants of consequence, recognized as contributing, producing, or participating actively in the construction of knowledge. (p. 3)

Nystrand et al.'s language about official answers, one-way evaluation, and the lack of opportunities for students to become "conversants of consequence" gestures toward a politics of recitation. While Freire (2000) does not mention recitation by name, it is easy to imagine that recitation, as a monological discourse, is a paradigm case of the oppressive "banking" concept of education, the opposite of dialogue. Such thinking about how recitation is oppressive and the ways this pedagogical oppression links to oppression in society at large amounts to claims about the politics of recitation. By politics I mean recitation's role in ideological reproduction, or the way recitation as an educational discourse teaches (maintains, perpetuates, communicates) existing social categories. Like Nystrand et al. and Freire, some theorists and researchers of education discourse understand recitation as an authoritarian form of classroom communication, characterizing other forms (discussion, dialogue, and debate) as being more in line with liberal democratic values (Backer, 2016a; Bridges, 1979; Burbules, 1993; Dillon, 1994; Haroutunian-Gordon, 2009; Hess, 2009; Mill, 2006; Parker, 2006, 2010; Sarid, 2012). However, few have examined recitation from a left-of-liberal perspective, such as Marxist, socialist, or critical pedagogy traditions. Gutierrez and Larson (1994) are one exception. 


\section{Recitation: A Hegemonic Discourse}

Critical pedagogues and leftist education researchers presume that schooling can play a reproductive and/or resistant role with respect to existing social categories. Researchers in critical pedagogy use the concepts hegemony, exclusion, closure, subordination, monopoly, and dominance in reference to education. Gutierrez and Larson (1994) look at recitation explicitly. To the extent that "school is not a neutral enterprise and ... [has a] role as socializing agent in the larger context of an unjust society," they reexamine "current assumption [s] about how people learn and study . . . at the micro-level in face-to-face interaction in classrooms" (p. 25). Identifying critical pedagogy as a central influence on and audience for their inquiry, they analyzed classroom interactions during a three-year ethnographic study of Latinx children in literacy classrooms. Their goal was to demonstrate how English as a second language (ESL) students, particularly young "Latino/a" children, are forced into the margins of learning through restricted access to certain forms of knowledge and legitimate participation (p. 33). They interpreted the ethnographic data through the lens of a "sociohistorical and sociocultural theory" that has "both a means ... and a language for describing human activity across contexts and the consequences of particular kinds of activity on the developing of particular kinds of skills and practices" (p. 25). Drawing also from language socialization theories and activity theories within this broad sociohistorical and sociocultural domain, Gutierrez and Larson characterize recitation as a classroom practice that is a construction "of both language and interactional processes" and "socially constituted events" (p. 25). This mixed framework permits them to make a claim about the politics of recitation using the notion of hegemony along with sociohistorical/sociocultural theory's emphasis on concrete practices. They conducted careful discourse analysis of literacy instruction with limited-English-speaking students and found that recitation is "hegemonic," arguing that

restricted forms of classroom discourse [like recitation] become both the "vehicle and destination" ... in that students are both socialized to particular forms of discourse and interaction, as well as socialized through the discourse of the classroom. In this way, socialization to larger societal norms and practices formally begins in the hegemonic language and interactional practices evident in traditional classrooms. (p. 26)

Recitation is a "form of classroom discourse" that is a "vehicle and destination" because it is a pattern of communication serving both as a content of socialization and a form of socialization. Gutierrez and Larson assert that it is a way of communicating a set of existing societal norms and practices and is a societal norm and practice itself. In the case of the Latinx children learning to read in English, recitation is a hegemonic discourse because:

First, the social and historical experiences that these students bring to the classroom are ignored or denied when students are provided few occasions to co- 
construct activity, discourse, and the content of the curriculum . . Moreover, recitation denies these students the opportunity to appropriate the cognitive, linguistic, and sociocultural knowledge that is most valued. (Gutierrez \& Larson, 1994, p. 33)

A recitation does not provide students with the opportunity to "co-construct activity, discourse, and the content of the curriculum," and it also denies students the opportunity to appropriate certain valued knowledge. Because of this, Gutierrez and Larson contend, recitation teaches children the prevailing social categories that marginalize Latinx students in society. Recitation is the vehicle and destination for these children to learn their place in society and thereby take their place in society. Recitation teaches them that they are a minority with fewer privileges than whites.

Citing Apple (1990) and Giroux (1992), Gutierrez and Larson (1994) claim that recitation is a hegemonic discourse because it is a "common sense . . practice" which "functions as a controlling force that dominates student and teacher ideology" (p. 22). They state that "hegemony needs to be understood as being the product not only of the larger social systems that define our society, but also as the product of the way individual classroom cultures are organized and constructed" (p.22). Thus, they invoke images of immigration control, claiming that recitation pedagogically "patrols the border," functioning like an education wall separating those with Latin American heritage from privileges accorded to majority groups. Through recitation, they say, "students are not allowed to become border crossers, that is, to enter the official community . . through hegemonic discourse and hierarchical participation structures, they remain marginal participants in a community that patrols its borders with vigilance" (p. 33). Recitation is a hegemonic discourse because it is a script that organizes and constructs the classroom space as one that marginalizes minority children according to existing marginalizations of the Latinx categories and, simultaneously, teaches children to accept these categories.

\section{Hegemony and Interpellation: A Clarification}

Gutierrez and Larson's (1994) claim that recitation is a hegemonic discourse is a reproductionist claim about the politics of recitation. They describe the way recitation transmits existing social categories, how it is a concrete practice that recruits individual students to prevailing ideologies. In their argument, Latinx students are taught, through recitation, to belong to a category of marginalized people in society. That they use the term hegemony for this claim about the politics of recitation, rather than interpellation, is quite interesting.

Education thinkers took up the term hegemony in the 1980s following Gramsci, who used it to refer to "a central system of practices, meanings and values, which we can properly call dominant and effective ... [and] are not merely abstract but are organized and lived" (Williams, 1973, p. 9). This emphasis on organized and lived practices, meanings, and values is salient for thinking about the relationship between school and society. There is a vast lit- 
erature on the concept of hegemony in Gramsci's thinking and a sizable subliterature on the concept of hegemony as it applies to education (Anderson, 2017; Borg, Buttigieg, \& Mayo, 2002; Fischman \& McLaren, 2005; Laclau \& Mouffe, 2001; Mayo, 2015a, 2015b).

Gramsci (1999) makes an important distinction between two concepts involved in achieving hegemony in the balance of forces: domination and leadership. Translators Hoare and Smith tell us that while Gramsci uses direzione and egemonia to refer to "leadership," there is an important conceptual difference with the latter, particularly the way Lenin took up the concept in his writings leading up to the Russian Revolution. Egemonia is a leadership-instruggle that any group, dominant or subordinate, can exercise in vindicating its ideology in the political terrain. In other words, domination is an outright subjugation of one group over another: "a social group dominates antagonistic groups, which it tends to 'liquidate,' or subjugate perhaps even by armed force” (Gramsci, 1999, p. 57). Yet, independent of whether a group is in the subjugating or subjugated position, it must "already exercise leadership before winning governmental power" (p. 57). Thus, there must be a kind of leadership that any group, subordinate or dominant, can exercise to vindicate its ideology. Hegemony is that kind of leadership, enacted through education and intellectual production, that dominating groups use to manufacture consent among individuals. But subjugated groups can also use hegemony to organize against the dominant group, independent of subjugation. Hegemony both explains "the spontaneous consent given by the great masses of the population to the general direction imposed on social life by the dominant group" ( $p$. 172) and permits a kind of educational independence from dominant forces.

Since both superior and inferior groups must lead their respective followers, each must establish consent to its ideologies, making hegemony a kind of leadership-in-struggle whether the group is in power or not. As Gramsci (1999) reads the Italian theorists of the nineteenth century and Lenin's use of the term, the concept of hegemony "gave new weight . . . to the front of cultural struggle" (p. 201), since groups can use this educational agency to mobilize their constituencies. In other words, the history of revolution shows us that intellectuals, teachers, and other cultural actors can lead subjugated groups to power despite the constraints of a dominant group. Hegemony names the kind of leadership that groups may use to establish consent no matter the existing balance of social forces. ${ }^{1}$

Since Gutierrez and Larson's argument for the politics of recitation concerns the marginalization of students according to dominant (rather than subjugated) ideologies in society, the concept of hegemony may not be the best way to describe the politics of recitation in this case. Hegemony does not differentiate between the educational agency that subordinate groups enact for themselves and the educational agency that dominant groups enact for themselves. Rather, hegemony names the consent either group can establish through leadership-in-struggle. Therefore, it would have been just as appro- 
priate if Gutierrez and Larson's study had focused on how Latinx children and teachers assert an educational agency despite the recitative script's marginalizing force on behalf of a dominant ideology. Recitation clearly helps dominant groups achieve a reigning hegemonic status by establishing consent to their ideologies, but the concept of hegemony does not by itself explain how leaders and authorities attempt to manufacture consent through concrete, immanent, and moment-to-moment interactions like recitation. The Althusserian concept of interpellation extends the Gramscian notion of hegemony, helpfully building out Gramsci's geological view of political struggle to explain the myriad concrete ways individuals become subject to dominant groups.

The philosophy of Althusser provides a clearer way to describe this politics of recitation as an interpellative, rather than hegemonic, discourse. Arguing that recitation is an interpellative discourse is a more accurate characterization of the politics of recitation in Gutierrez and Larson's analysis, since hegemony names the more general leadership-in-struggle that groups exhibit when establishing consent to vindicate their ideologies in the political terrain. Gutierrez and Larson are concerned with how dominant groups do this concretely through recitation. Interpellation is the better fit.

For Althusser (2014), ideology is an "imaginary relationship of individuals to their real conditions of existence" (p. 256). Rehmann (2014) explains that Althusser's is an ideology theory rather than an ideology critique: a more neutral understanding of ideology as a vision of the social world, rather than a tool that one group uses to distort the world for their particular purposes. Ideology in this sense is how anyone, no matter their position in the terrain, imagines what society is really like. Althusser's ideology theory is not dissimilar to the way Gutierrez and Larson (1994) talk about socialization and social norms, categories, and meanings. Ideology is what one is socialized into; when one is told to "get with the program," ideology is the program. Interpellation, for Althusser, is the function of ideology, or what Eagleton (1991) calls "ideology in practice" (p. 121), how ideology is lived through actions, gestures, and movements. Interpellations are movements and gestures that human beings make that propagate a vision of the social world. Althusser (2014) writes that "ideology 'acts' or 'functions' in such a way as to 'recruit' subjects among individuals ... or 'transforms' individuals into subjects . . through the very precise operation that we call interpellation or hailing" (p. 190). Continuing with the pedestrian phrase "get with the program," the term individual in this passage refers to someone who has not yet gotten with a particular program. An individual, in this sense, might be called an idiot (Greek idios) - someone who does not follow a particular set of social norms. Interpellation, therefore, has a recruiting function in that it hails an individual and makes them subject to a dominant ideology. An interpellation is a concrete, lived moment when someone who is not with the program is compelled to get with the program. Interpellation thus recruits individuals by making them subject to dominant ideology. Dolar (1993) likens this process to falling in love, only in interpella- 
tion one "falls into ideology." Althusser (2014) gives an allegorical example of this transition from individuality to becoming a subject of dominant ideology, telling the story of a police officer hailing a citizen:

There are individuals walking along. Somewhere (usually behind them) the hail rings out, "Hey, you there!" An individual ... turns around, believing-suspectingknowing that he is the one-recognizing, in other words, that he "really is the person" the interpellation is aimed at. In reality, however, things happen without succession. (p. 191)

The police officer, ensuring law and order, is a representative of dominant authority and so becomes a recruiter for the dominant ideology. In the sequence of this situation, the actual hailing by the police officer combined with the individual turning around completes the interpellation. The situation is both literal and metaphorical: interpellation is when a representative of dominant authority does something to "turn" an individual who is not recruited by the dominant ideology, making them subject to that ideology. An individual becomes subject to dominant ideology when hailed by a representative of that dominant ideology, thus learning the prevailing imagined relations to real conditions in that society. ${ }^{2}$ The citizen, in this case, has become a subject of the state, hailed by the commanding gaze of one of its representatives. However, in reality, Althusser writes, things happen without succession; an interpellation could make an individual subject to dominant ideology in a variety of ways or patterns. An interpellation must be as explicit and concrete as a police officer hailing and a citizen turning to face the officer. According to Montag (1996), the interpellative process is how a dominant group establishes consent to its ideology.

Why did Gutierrez and Larson (1994) use hegemony rather than interpellation in their politics of recitation? A fierce debate took place over these words in social theory and sociology of education, between scholars working in reproductionist and resistance paradigms when thinking through the relationship between schooling and society. Though resistance theories and subcultural theories of schooling had fully formed before Willis's work (McGrew, 2011), the premises of this disagreement between reproduction and resistance more or less originated with Willis's (1977) landmark Learning to Labour: How Working Class Kids Get Working Class Jobs and his subsequent essays on reproduction (1981, 1983). Learning to Labour is an ethnographic and theoretical demonstration of how a particular group of subordinate working-class students (the "lads") blocked, complicated, and resisted their school's attempt to recruit them into dominant ideologies. The theoretical significance of Willis's account posed, he argued, a problem for theories which claimed that schools merely transmit dominant ideologies. While Willis did not use hegemony to describe his theoretical intervention, Gordon (1984) situates Willis's claims in terms of the Gramscian idea that subordinate groups, despite their subordination, can lead themselves as part of a struggle against superior groups. Willis $(1981,1983)$ 
extended and defended this intervention by distinguishing his approach from the more "restrictive" claims made by Bowles and Gintis (1976), Althusser (2014), Bourdieu and Passeron (1990), and Bernstein (2000), theorists he claimed limited the creative, collective agency afforded to subordinate groups by cultural production. ${ }^{3}$ Willis (1983) accused the reproductionist theories of being mechanical and functionalist, configuring the term reproduction to refer to a limiting, restrictive, and confining theory. The reproduction-resistance dichotomy was thus born in educational thinking about society, and hegemony came to connote a subordinated group's potential for resistance, agency, and autonomy while caught in an unequal power relationship with another group. Interpellation came to mean the opposite- a mechanical process that constrains the agency of subordinated groups by fully dominating them. While there remains considerable tension between resistance theorists and reproduction theorists, the distinction between their use of the determination/freedom dyad is more superficial than it appears. The most significant complaint against theorists like Althusser (who is grouped with Bowles and Gintis [1976] and Bourdieu and Passeron [1990]) is that their theory of interpellation is mechanical and does not permit the agency-in-subordination that Gramsci's hegemony affords to subjugated groups. This is a misreading of Althusser's immanent philosophy of education, however, and is an avenue for further research. ${ }^{4}$

This association of hegemony with agentic resistance, and interpellation with a reproductive lack of agency, makes Gutierrez and Larson's argument that recitation is a hegemonic discourse easier to understand. Willis's (1981, 1983) reading of Althusser has dominated the history of education thinking. ${ }^{5}$ Apple (1990) and Giroux (1992) more or less followed Willis in this interpretation, and Gutierrez and Larson (1994) cite Apple and Giroux as major influences. The acceptance of Willis's reading, and Gordon's (1984) subsequent placement of Willis in a Gramscian tradition of hegemony, is most likely why Gutierrez and Larson do not mention interpellation and use hegemony in their argument. While Walker (1986) and McGrew (2011) have critiqued the traditions of critical theory and critical pedagogy flowing downstream from Willis's thinking, the mechanistic interpretation of concepts like interpellation has remained the canonical one in critical theory and sociology of education.

This article may be considered part of a larger project to challenge such interpretations, since they do not take important aspects of their target philosophies into account and, practically speaking, limit the theoretical resources available to understand the politics of schooling. Althusser's immanent philosophy, for example, is a robust antidote to mechanical understandings of economy and ideology. Althusserianism is an important augmentation of the Gramscian geological view of political struggle, and an explicit challenge to the Stalinist interpretation of Marxist philosophy (Elliott, 2006). There have also been important advances in Althusserian philosophy that address concerns like those expressed by Willis (Williams, 1993; Dolar, 1993; Lock, 1996; 
Elliott, 2006; Lecercle, 2006; Montag, 2013). The literature around the concept of interpellation since 1990 is important to examine in this context. One key concept worth developing from that literature is Lecercle's (2006) notion of counterinterpellation, which completes Althusser's account of the interpellative process by describing how speakers creatively exploit and appropriate interpellations for unique purposes (Backer, 2016a). A counterinterpellation insults the insult of the original interpellation, taking up and taking on dominant ideology by formulating and propagating counter-ideologies (Lecercle, 2006, p. 140).

While fully pursuing this matter is outside the scope of this article, it is an important thread to follow for further research. My intention here is to look at the history of education thinking to see how hegemony became hegemonic, so to speak, and thus why it was used to understand the politics of recitation instead of interpellation, which is the better concept. My ultimate aim is to augment Gutierrez and Larson's politics of recitation, taking it from being a theory that understands recitation as an educational discourse that recruits individuals to particular social categories to one that more generally understands recitation as a form of education discourse that teaches individuals to be recruitable for any social category. While interpellation has figured heavily in critical education research (a Google Scholar search for "interpellation and education" yielded nearly one thousand articles in 2016 alone), the idea has not been applied robustly to education discourse analysis or to recitation specifically (De Lissovoy, 2008; Pereira, 1991).

\section{The Interpellation Thesis}

Is recitation an interpellative discourse? While the police officer example is the best-known example of interpellation, Althusser (2014) also claims that interpellation "functions in very similar forms . . . at school" (p. 190). Though he does not elaborate that recitation is one such form, I contend that recitation is an educational interpellation.

Althusser (2014) is careful to say that, "in reality, things happen without succession" (p.190)—an interpellation can happen in another order or sequence, insofar as an action makes an individual subject to dominant ideology, turning them to that ideology. For Althusser, "turning" is metaphorical. It is the moment someone gets with an ideological program. In this sense, recitation is a good candidate for interpellation: the teacher addresses the students, students respond to the teacher's question, the teacher approves or disapproves. Each repetition of the IRE script enacts an interpellation. When the teacher's eyes fall on the student in a recitation, this student metaphorically turns around, "recognizing that he "really is the person" the recitation is aimed at (p. 191). Some scholars have made this connection between teacher talk and interpellation, though not for explicitly political purposes. Pereira (1991), for example, thinks of a teacher question as a "non-assertive enunciation-at least 
in its most common form-which corresponds, in some way, to the solicitation of a particular student or set of students who form a class" (p. 168).

Though this usage of interpellation is depoliticized, the interpellation thesis for the politics of recitation is nonetheless present. In a teacher's "nonassertive enunciation," a question is put to a student during a recitation, the teacher "solicits" the students. Menezes, Guerreiro, Martinho, and Ferreira's (2013) concept of solicitation is precisely the recruiting and hailing function Althusser attributes to interpellation. For Althusser, representatives of authority solicit individuals when recruiting them to the dominant ideology. In this sense, when recitation solicits students, there is an ideological significance in the gesture. This solicitation feature of recitation is reminiscent of Gutierrez and Larson's (1994) vehicle and destination argument for the politics of recitation. While Pereira and Menezes et al. do not go on to argue for the ideological significance of the solicitation, Gutierrez and Larson claim that the Latinx students they observed were socialized into their marginal status through the recitation. Through teachers' questions, those students were solicited while they were learning how to read in English. And during the course of that solicitation, they were interpellated into marginalized categories. Through the recitation, therefore, students got with the program of marginalization. Here, then, is the interpellation thesis for the politics of recitation: recitation is a script that recruits individual students to dominant ideologies through solicitations, questions, and, generally, the initiation-response-evaluation script of recitation. I have thus recast Gutierrez and Larson's claim that recitation is a hegemonic discourse to say that recitation is a discourse of interpellation to particular categories.

\section{The Interpellatability Thesis}

Yet there remains an ambiguity even in this recast thesis, one exemplified in Gutierrez and Larson's use of the terms language and discourse to describe both the process of recitation and the products of the dominant culture, which they argue recitation preserves. There are subtle differences between kinds of discourse. Throughout their framework, Gutierrez and Larson refer to both educational patterns of communication and knowledge, both practices and meanings, both activities and norms. For them, recitation is a practice that communicates a norm. However, they frequently conflate practices and norms, two distinct types of discourse, often mentioning them in the same breath. Practices and norms are quite different, one is process and the other product, and the ambiguity in Gutierrez and Larson's framework creates a difficulty for the interpellation thesis of the politics of recitation. Discourse can include meanings, contents of knowledge, and symbols (discursive products), as well as speech acts, scripts, and interactional patterns (discursive processes). As the authors imply with their vehicle and destination metaphor, discursive contents are communicated through the discursive forms. In other words, contents of classroom discourse can shift in dramatic ways, while the forms of 
classroom discourse stay the same. One can converse about movies or physics or politics, for example, but the conversation as a form of discourse remains constant even while the discursive content shifts.

A precedent for this distinction between process and product of discourse may be found in the work of early-twentieth-century Marxist philosopher of language Valentin Volosinov (whose potential as a philosopher of education, Peters [2011] claims, has yet to be actualized). Volosinov (1973) describes the ideological significance of both forms and contents of discourse, distinguishing between words and the verbal forms of communication in which words are spoken. The former can contain themes, and the latter are ways in which "themes are implemented" (p. 21). For example, using the word man to refer to humanity has a sexist theme, but words are not the only bearers of such themes. He writes that "words cannot substitute a religious ritual" (p. 21), for example. In this case the ritual is an ideological sign as well as the words spoken during the ritual. Forms of discourse include the way we talk; the forms of how we communicate (not what we say but how we say it) are ideological as well. Going back to the example of a conversation about many topics, Volosinov's claim is that conversations, as well as topics of conversation, have ideological qualities. Conversation in this case is a form of discourse with ideological significance. Forms of discourse include "unofficial discussions, exchanges of opinion ... purely chance exchange of words" (p. 21). The ideological significance of a stranger on the street saying the word man to describe all humans in a passing conversation is different than when a president says it in a speech. Volosinov goes so far as to say that verbal forms of discourse are a "concrete implementation of the spirit [of the age]" (p. 21), and he calls these forms of interaction "behavioral ideology."

Though Volosinov does not mention recitation, classroom discourses like recitation are examples of forms of discourse that enact ideology in distinct ways independent from the contents of discourse. Gutierrez and Larson do not distinguish clearly between the form and content of recitation. While their work stands out as the first and best political analysis of recitation, this ambiguity between form and content of discourse haunts their argument, which in some places addresses content and in others addresses form. I stand on the shoulders of this important work, departing from it while also critiquing it, and articulate a more general thesis about the politics of recitation as a discourse of interpellatability rather than an interpellative discourse. Whereas the former is a more general claim about how recitation teaches students to become recruitable for any category, the latter is a more specific claim about how particular recitations recruit students for particular categories. The distinction between interpellative discourse and discourse of interpellatability follows from the ambiguity between form and content in Gutierrez and Larson's framework.

For purposes of illustration consider a liberatory recitation, taking liberation in a general way to mean a non-reformist shift in social relations away from 
exploitation, oppression, or injustice. Teachers can and do challenge such relations in their classrooms. ${ }^{6}$ Lesson plans written by socially conscious teachers and professors can address any number of oppressive relations, taking oppressive to mean the opposite of liberatory in the same general sense as above. During such lessons the content of classroom discourse is presumably liberatory. Given that recitation is a frequent default educational script, it is likely that teachers use recitation to teach their liberatory lesson plans (e.g., Husband, 2014, p. 34). Does Gutierrez and Larson's thesis extend to this case? When teaching liberatory content, is the recitative script, as a form of discourse, a discourse of interpellation? If the content of the recitation is liberatory, does the form of discourse make students subject to a particular dominant ideology? The content in the liberatory lesson is actually counterhegemonic, as it is a counterinterpellation that challenges the hegemony of superior forces. But what about the form? The thesis that recitation is a discourse of interpellation recruiting students to a particular ideology refers to the content of particular recitations, but does not address the form of recitation as a classroom discourse independent of content. Gutierrez and Larson's thesis is therefore not about recitation in general but is instead about the marginalizing discursive contents present in the particular recitations they observed. They mistake a tree for the forest in this case: since the recitations they observed interpellated students for a particular ideology, basically a variant of white supremacy that marginalizes Latinx students, they conclude that all recitations interpellate some particular dominant ideology. Using their metaphor of vehicle and destination, their argument does not fulfill its promise to give a politics of recitation as both a vehicle and a destination of interpellation; it only presents a particular set of recitations as vehicles toward marginalization, but not the destination of recitation in general.

The first moment of the recitation, independent of what the recitation is about, is a demand to present oneself to an authority figure. The first question a teacher asks during recitation is also a demand for a student to individuate themselves and answer the question. This question is a kind of hailing, as Pereira (1991) implies: a solicitation. The teacher hailing a student during recitation is different than the police officer hailing an individual on the street, however. Whereas the police officer demands that the individual become subject to a dominant ideology, the teacher demands that an individual student become subject to the process of solicitation. Whereas the police officer commands a particular individual to be hailed by saying, "Hey you!," the teacher, during recitation, teaches students how to be hailed by asking them questions, addressing them over and over again. In other words, the police officer hails individuals, while the teacher, in a recitation, teaches individuals how to be hailed by hailing them again and again. Becoming subject to dominant ideology, being hailable in general, is something one must learn to do. We are not born knowing how to be properly interpellated, as the literature on student resistance clearly shows. Recitation, as a form of discourse, is therefore instruc- 
tion in being hailed-it is ideological reproduction, in general, manifest. Participation in a recitation teaches individual students how to be interpellated in general. ${ }^{7}$ Recitation is an education in becoming the kind of person who turns when a police officer calls out, "Hey you!" It is a preparation for future interpellations, a lesson in interpellatability.

The politics of recitation inherent in this interpellatability thesis shows that recitation teaches students to become able to be interpellated in general, for any category. Interpellatability is more general than Gutierrez and Larson's thesis. For them, recitation is a hegemonic discourse in that it interpellates students into a particular social category. The interpellatability thesis claims, however, that recitation is a hegemonic discourse in that it prepares students to be easily interpellated to any social category. Whether society is capitalist, communist, or feudal (or the inevitable mixture thereof), whether it is racist, sexist, ageist, ableist (or the intersectional mixture thereof [Ken, 2008]), recitation prepares students to be interpellated by whatever social categories are present in social relations at that moment in the political terrain.

The interpellatability thesis solves the liberatory recitation problem posed earlier. Even during a lesson whose content is liberatory, a recitation will still teach interpellatability: while the lesson's content may be liberatory, the form is a hegemonic practice because it teaches students to become interpellatable. In addition to the liberatory lesson on class, race, or gender oppression, or whatever the case may be, if that lesson is taught through recitation, there is yet another lesson taught about how to be interpellated, how to be hailed and recruited, how to turn and be turned to dominant ideology in general. Thus, with the interpellatability thesis, it is impossible for recitation to be fully liberating; it can be only partially liberating.

Whereas the interpellation thesis of the politics of recitation claims that recitation interpellates students into some particular social category or relation, the interpellatability thesis claims that recitation instructs students on how to become interpellatable for any ideology in general. To be clear, the claim here is not that teachers intentionally facilitate recitations because they have an explicit goal of making their students interpellatable. The practice of recitation has been handed down across many generations of teachers and students; Hoetker and Ahlbrand (1969) trace it back to 1892, using some of the earliest classroom discourse research available. Recitation therefore persists structurally, not as the intentional choice of teachers. In this vein, the interpellatability thesis generates a response as to why recitation persists in this way. This response is one of the explicit contributions of this article, and it opens up new avenues for research.

\section{Contributions and Directions for Further Research}

The first contribution of this article is to point out that there is a politics of recitation. Only one systematic analysis of recitation's politics exists, and it is Guti- 
errez and Larson's (1994) claim that recitation is a hegemonic discourse. The second contribution is the suggestion that interpellation better describes this politics of recitation than hegemony does. The third contribution is the speculation that misreadings of Althusser in the history of sociology of education created an intellectual discourse in which it was appropriate for Gutierrez and Larson to use hegemony rather than interpellation in their analysis. The fourth contribution is the articulation of the interpellatability thesis for the politics of recitation-that it is a discourse of interpellatability and not an interpellative discourse. As a final contribution, this thesis provides an answer to two important questions posed at the end of Hoetker and Ahlbrand's (1969) survey of recitation's persistence from 1892 to 1968. The first question the authors ask is about recitation itself: "What is there about the recitation . . . that makes it so singularly successful in the evolutionary struggle with other, more highly recommended, methods?" (p. 163). The second question they ask is about education research and teacher training: "If the recitation is a poor pedagogical method, as most teacher educators long have believed, why have they not been able to deter teachers from using it?" (p. 163). While there have been many confirmations of Hoetker and Ahlbrand's findings (e.g., Nystrand et al., 2003), and just as many suggestions for how to teach without recitation, these questions about recitation's persistence endure. Why is recitation still the default pattern of education discourse despite generations of attempts to unseat it?

According to the interpellatability thesis, recitation persists because of its ideological efficacy across contexts: it teaches young people to become interpellatable to any social category. Per this view, recitation persists because it teaches children to be hailed by any existing authority and thereby recruited for existing social categories, whatever those categories might be. Recitation is a highly effective discourse of interpellatability. Dillon (1994), in an analysis of a forty-minute recitation, found that teacher-student turns (where the teacher addresses an individual student with a question and then follows up with an evaluation) composed 88 percent of the discourse (p. 17). According to the interpellatability thesis, each teacher-student turn is a practice hailing. During the IRE script, students learn how to be recruited by an authority without issue, and thereby made subject to the dominant ideology (whatever that happens to be) in an effective way. This efficacy is one reason why recitation persists so powerfully across generations; it is a powerful script for sculpting interpellatable individuals, who are valuable assets for societies of any size, be they classrooms, schools, civil society, or the state. Using the language of Althusserian reproduction theory, according to the interpellatability thesis, recitation is a concrete function of school reproduction: an observable, concrete, and everyday practice that makes students recruitable to hegemonic social relations.

The interpellatability thesis points to several avenues for further research. One such avenue could examine whether and how teacher education works 
against recitation's persistence, given that it is such an effective tool in teaching interpellatability. If teacher education programs address the political significance of recitation explicitly, might they go further in rooting it out as the default education script? What would that teacher preparation curriculum look like? If one believes that schooling is a reproductive apparatus in social structure and that recitation is an effective concrete practice of this reproduction, is rooting out recitation even possible? Another avenue for further research could study the persistence of recitation across other national contexts and time periods. Are Hoetker and Ahlbrand's conclusions true for other societies over the last one hundred years? Is the persistence and frequency of recitation at all correlated with the stability of societies, such as those undergoing revolutions or internal rifts? What is the relationship between recitation as an educational script and the ideological strength of particular societies? Yet another path for research flowing from this essay could be further examination of the concept of reproduction in the history of sociology of education, specifically revisiting Althusser's idea of interpellation. How have the conceptions of reproduction by cultural production theorists, for example, configured our understanding of the relationship between school and society? How have these conceptions of reproduction configured our understanding of ideology and education in general? Further, how can newer readings of Althusser that clarify and extend his philosophy—such as Lecercle's idea of counterinterpellation-be applied in educational research, specifically to theories of student resistance and subculture? Finally, in combining these theoretical questions with the historical and empirical questions raised about recitation across geographical and national contexts, a final avenue for further research could be the adoption of interpellation into education discourse analysis. To what extent is interpellation measurable with the tools of discourse analysis? Are classroom discourse analyses also analyses of the success and failure of its making students interpellatable?

In this article, in summary, I argue for a new understanding of the politics of recitation as it is understood by education discourse analysts such as Hoetker and Ahlbrand, Cazden, Nystrand et al., and Parker. I contend that, first, the role recitation plays in ideological reproduction should be understood in terms of interpellation and not just hegemony. Second, recitation does not interpellate students into a particular category but rather also teaches students to become interpellatable to any category independent of social context. Recitation is a discourse of interpellatability, not an interpellative discourse. The interpellatability thesis contributes to the existing literature on recitation by giving a political response to the question of recitation's persistence over more than a century of education discourse analysis, and it opens new possibilities for research to investigate further the connection between recitation and ideology. 


\section{Notes}

1. See Schwarzmantel (2014) for more on Gramsci's view of school in the process of subaltern groups achieving hegemony. For more on the relationship among hegemony, language, and the balance of forces as conceived by Gramsci (and its implications for education), see Backer (2016a).

2. Althusser's theory of subjectivity, and its psychoanalytic heritage, is important to note here. Althusser was influenced by French psychoanalyst Jacques Lacan, specifically in his articulation of ideology as an imagined relation, though this stream of thinking is outside the scope of this essay. For more on the connection between Lacan and recitation, see Backer (2017). For more on the connection between Althusser, Lacan, and ideology, see Rehmann (2014), pp.160-173.

3. It is interesting to note that these may have been the same critiques leveled at Willis's (1977) Learning to Labour, and Willis's motivation to distance himself from such accusations may have been quite intense given his historical context. These debates were happening at the height of the Cold War, after a generation of virulent anticommunism in the United States and elsewhere. Scholars affiliated and unaffiliated with the Communist Party, as well as in different traditions of Marxist thinking, fought with each other over these questions (e.g., Thompson versus Althusser). The stakes were high. Accusations of determinism and economism could imply support for Stalinist totalitarianism, while a lack of revolutionary authenticity in one's theory could imply support for imperial capitalism. Thus, a certain electricity ran through this intellectual conversation, distorting the meanings of its theoretical terms. Perhaps only now, after the 2008 financial crisis, Brexit, and Donald Trump's election, at the twilight of a neoliberal hegemony ruling classes achieved after 1990, only now given this significant shift in the global political terrain, can we think about these ideas with clearer heads.

4. For an updated articulation of the reproduction perspective for a general audience, see Backer (2016b).

5. Willis (1981) is particularly acidic in his critique: "What gives to Althusser his specious fullness is, in fact, an implicit or highly simplistic theory ... [which] pictures the working class as totally dominated and, indeed, fully 'interpellated"” by capital" (p. 52). This misreading of Althusser was common at the time, even among Willis's most ardent critics (Gordon, 1984; Walker, 1986).

6. See Husband (2014) and Dover (2013) for contemporary examples of liberatory lesson plans.

7. This claim maps somewhat to Althusser's (2014, p.193) distinction between particular ideologies and ideologies in general. His argument is psychoanalytic: ideology exists in any society at any historical moment, though the contents of this ideology differ dramatically, much like the unconscious will exist in any individual psyche, though the contents of that unconscious differ dramatically from person to person.

\section{References}

Althusser, L. (2014). On the reproduction of capitalism. London: Verso.

Anderson, P. (2017). The H-word: The peripeteia of hegemony. Verso Books.

Apple, M. W. (1990). Ideology and curriculum (2nd ed.). New York: Routledge.

Apple, M. W. (2012). Education and power. Routledge Education Classic Edition. New York: Routledge. doi:10.4324/9780203241219

Backer, D. I. (2016a). Towards an activist theory of language. In J. Hannan (Ed.), Truth in the public sphere (pp. 3-22). Lanham, MD: Lexington Books. 
Backer, D. I. (2016b, November 15). The false promise of education. Jacobin Magazine. Retrieved from https://www.jacobinmag.com/2016/11/education-reforminequality-jobs-economy/

Backer, D. I. (2017). The mass psychology of classroom discourse. Educational Theory, 67(1), 67-82. doi:10.1111/edth.12228

Bellack, A. A., Hyman, R. T., Kliebard, H. M, \& Smith, F. L. (1962). The language of the classroom. New York: Teachers College Press.

Bernstein, B. B. (2000). Pedagogy, symbolic control, and identity: Theory, research, critique. New York: Rowman \& Littlefield.

Borg, C., Buttigieg, J. A., \& Mayo, P. (2002). Gramsci and education. New York: Rowman \& Littlefield.

Bourdieu, P., \& Passeron, J. C. (1990). Reproduction in education, society and culture. New York: Sage.

Bowles, S., \& Gintis, H. (1976). Schooling in capitalist America. New York: Basic Books.

Bridges, D. (1979). Education, democracy, and discussion. Windsor, UK: NFER.

Burbules, N. (1993). Dialogue in teaching: Theory and practice. New York: Teachers College Press.

Cazden, C. (1986). Classroom discourse: The language of teaching and learning. Portsmouth, NH: Heinemann.

De Lissovoy, N. (2008). Power, crisis, and education for liberation. New York: Palgrave Macmillan. doi:10.1057/9780230612976

Dewey, J. (1998). How we think. Boston: Houghton-Mifflin.

Dillon, J. T. (1994). Using discussion in classrooms. London: Open University Press.

Dolar, M. (1993). Beyond interpellation. Qui Parle, 6(2), 75-96.

Dover, A. G. (2013). Teaching for social justice: From conceptual frameworks to classroom practices. Multicultural Perspectives, 15(1), 3-11. doi:10.1080/15210960.2013.754285

Eagleton, T. (1991). Ideology: An introduction. London: Verso.

Elliott, G. (2006). Althusser: The detour of theory. Leiden, Netherlands: Brill. (Original work published 1987)

Fischman, G. E., \& McLaren, P. (2005). Rethinking critical pedagogy and the Gramscian and Freirean legacies: From organic to committed intellectuals or critical pedagogy, commitment, and praxis. Cultural Studies $\leftrightarrow$ Critical Methodologies, 5(4), 425-446. doi: $10.1177 / 1532708605279701$

Ford, D. R. (2016). Communist study: Education for the commons. Lanham, MD: Lexington.

Freire, P. (2000). Pedagogy of the oppressed. London, UK: Bloomsbury.

Giroux, H. (1992). Border crossings: Cultural workers and the politics of education. New York: Routledge.

Goodlad, J. I., \& Klein, M. F. (1974). Looking behind the classroom door: A useful guide to observing schools in action. New York: Jones.

Gordon, L. (1984). Paul Willis-Education, cultural production and social reproduction. British Journal of Sociology of Education, 5(2), 105-115. doi:10.1080/0142569840050201

Gramsci, A. (1999). Selections from the prison notebooks of Antonio Gramsci (Q. Hoare, Ed.). New York: International.

Gutierrez, K., \& Larson, J. (1994). Language borders: Recitation as hegemonic discourse. International Journal of Educational Reform, 3(1), 22-36.

Haroutunian-Gordon, S. (2009). Learning to teach through discussion: The art of turning the soul. New Haven, CT: Yale University Press. doi:10.12987/yale/9780300120004.001.0001

Hess, D. (2009). Controversy in the classroom: The democratic power of discussion. New York: Routledge.

Hoetker, J., \& Ahlbrand, W. P., Jr. (1969). The persistence of the recitation. American Educational Research Journal, 6(2), 145-167. doi:10.3102/00028312006002145 
Husband, T. (2014). Using drama pedagogy to develop critical racial literacy in an early childhood classroom. Perspectives and Provocations, 4(1), 16-50.

Joyce, B., \& Calhoun, C. (2014). The conduct of inquiry on teaching: The search for a more effective method than recitation. In Hargreaves, A., Lieberman, A., Fullan, M., \& Hopkins, D. (Eds.), Second international handbook of educational change: Part Two. New York: Springer Science \& Business Media.

Ken, I. (2008). Beyond the intersection: A new culinary metaphor for race-class-gender studies. Sociological Theory, 26(2), 152-172. doi:10.1111/j.1467-9558.2008.00323.x

Laclau, E., \& Mouffe, C. (2001). Hegemony and socialist strategy: Towards a radical democratic politics. London: Verso.

Lecercle, J. J. (2006). A Marxist philosophy of language (G. Elliott, Trans.). Leiden, Netherlands: Brill.

Lock, G. (1996). Subject, interpellation, and ideology. In A. Callari \& D. F. Ruccio (Eds.), Postmodern materialism and the future of Marxist theory: Essays in the Althusserian tradition (pp. 69-91). London: Wesleyan University Press.

Malott, C., \& Ford, D. (2015). Marx, capital, and education: Towards a critical pedagogy of becoming. Bern, Switzerland: Peter Lang. doi:10.3726/978-1-4539-1602-5

Mayo, P. (2015a). Hegemony and education under neoliberalism: Insights from Gramsci. New York: Routledge.

Mayo, P. (2015b). Antonio Gramsci's impact on critical pedagogy. Critical Sociology, 41(7-8), 1121-1136. doi:10.1177/0896920513512694

McGrew, K. (2011) . A review of class-based theories of student resistance in education: Mapping the origins and influence of Learning to Labor by Paul Willis. Review of Educational Research, 81(2), 234-266. doi:10.3102/0034654311402358

Menezes, L., Guerreiro, A., Martinho, M. H., \& Ferreira, R. A. T. (2013). Essay on the role of teachers' questioning in inquiry-based mathematics teaching. Sisyphus: Journal of Education, 1(3), 44-75.

Mill, J. S. (2006). On Liberty. Chicago: Pearson. (Original work published 1846)

Montag, W. (1996). Althusser, Spinoza, Hobbes. In A. Callari \& D. F. Ruccio (Eds.), Postmodern materialism and the future of Marxist theory: Essays in the Althusserian tradition (pp. 91-109). Middletown, CT: Wesleyan University Press.

Montag, W. (2013). Althusser and his contemporaries. Durham, NC: Duke University Press. doi:10.1215/9780822399049

Nystrand, M., Wu, L. L., Gamoran, A., Zeiser, S., \& Long, D. A. (2003). Questions in time: Investigating the structure and dynamics of unfolding classroom discourse. Discourse Processes, 35(2), 135-198. doi:10.1207/S15326950DP3502_3

Parker, W. C. (2006). Public discourses in schools: Purposes, problems, possibilities. Educational Researcher, 25(8), 11-18. doi:10.3102/0013189X035008011

Parker, W. C. (2010). Listening to strangers: Classroom discussion in democratic education. Teachers College Record, 112(11), 2815-2832.

Pereira, A. (1991). Comunicação e ensino das ciências: Contributo para o estudo da pergunta no discurso da aula de ciências do ensino básico. Unpublished master's thesis, University of Lisbon.

Peters, M. (2011). The Bakhtin circle, philosophy of language, and educational theory. In E. J. White \& M. A. Peters (Eds.), Bakhtinian pedagogy: Opportunities and challenges for research, policy and practice in education across the globe (pp. 247-260). Bern, Switzerland: P. Lang.

Rehmann, J. (2014). Theories of ideology: The powers of alienation and subjection. Chicago: Haymarket.

Sarid, A. (2012). Systematic thinking on dialogical education. Educational Philosophy and Theory, 44(9), 926-941. doi:10.1111/j.1469-5812.2011.00757.x 
Schwarzmantel, J. (2014). The Routledge guidebook to Gramsci’s Prison Notebooks. New York: Routledge.

Sirotnik, K. A. (1983). What you see is what you get-Consistency, persistency, and mediocrity in classrooms. Harvard Educational Review, 53(1), 16-31. doi:10.17763/ haer.53.1.9645457u7030m285

Stalin, J. (1939). Dialectical and historical materialism (p. 108). Foreign Languages Publishing House.

Stodolsky, S. S., Ferguson, T. L., \& Wimpelberg, K. (1981). The recitation persists, but what does it look like? Journal of Curriculum Studies, 13(2), 121-130. doi: $10.1080 / 0022027810130206$

Thayer, V. T. (1928). The passing of the recitation. New York: DC Heath.

Volosinov, V. N. (1973). Marxism and the philosophy of language (L. Matejka \& I. R. Titunik, Trans.). Cambridge, MA: Seminar Press.

Walker, J. C. (1986). Romanticising resistance, romanticising culture: Problems in Willis's theory of cultural production. British Journal of Sociology of Education, 7(1), 59-80. doi:10.1080/0142569860070104

Williams, L. (1993). Althusser on ideology: A reassessment. New Political Science, 14(1), 47-66. doi:10.1080/07393149308429699

Williams, R. (1973). Base and superstructure in Marxist cultural theory. New Left Review, $82(3), 5-16$.

Willis, P. (1977). Learning to labour: How working class kids get working class jobs. New York: Columbia University Press.

Willis, P. (1981). Cultural production is different from cultural reproduction is different from social reproduction is different from reproduction. Interchange, 12(2), 48-67. doi:10.1007/BF01192107

Willis, P. (1983). Cultural production and theories of reproduction. In L. Barton \& S. Walker (Eds). Race, Class, and Education. (pp. 107-138). London: Taylor \& Francis.

\section{Acknowledgments}

Excerpts from Nystrand, M., Wu, L. L., Gamoran, A., Zeiser, S., \& Long, D. A. (2003). Questions in time: Investigating the structure and dynamics of unfolding classroom discourse. Discourse Processes, 35(2), 135-198, reprinted by permission of the Society of Text and Discourse, www.societyfortextanddiscourse.org 
This article has been reprinted with permission of the Harvard Educational Review (ISSN 0017-8055) for personal use only. Posting on a public website or on a listserv is not allowed. Any other use, print or electronic, will require written permission from the Review. You may subscribe to HER at www.harvardeducationalreview.org. HER is published quarterly by the Harvard Education Publishing Group, 8 Story Street, Cambridge, MA 02138, tel. 617-4953432. Copyright (C) by the President and Fellows of Harvard College. All rights reserved. 